\title{
Currants, Currents, Undercurrents
}

Each day she permits herself only a green apple and a handful of currants which, with water, she tongues slowly one by one.

Her sole work of art: her body. Slowly, for him, she sculpts it and the planes of her face.

Crumbs on water swell into elusive white blossoms, vanishing bridal bouquet. As she treads to stay above the glazed surface, she watches mallards, webs sculling, circle her, creatures who mate for life. Any female-mate lost-must forever solo.

Falling water, I warn them both, cannot be dammed. Involved yet not, I watch their liquid dance of death. He cradles her head, and still the whirlpool sucks them in concentric circles, holds them breathless. At last, to save himself, he'll push off alone and rise up from the river's rocked bottom,

rise and fly a white dream plane past glaciers and a skullshaped cloud. Between peaks another cloud, in refracted light, a large cut-diamond. Above the polar cap, a ridged, uncanny moonscape.

If a mountain splits open at midnight and no one sees it, does the cloud behind it become a question mark?

Her aqua solo was part of another life, that lost Hollywood rubber-flowers-on-the-cap one. Ballet in blue water was trickier than on land. Never enough breath, an extension too hard, as she worried if anyone would ever love her enough. Moving water, never the same place, hard to stay in place, her body then

as always, as now-a traitor. 
Any bottom, I know, is another false bottom-like those in my green leather jewel box. Compartments inside compartments

until, with the flick of a pin, one with a diamond springs open.

The would-be bride has no diamond, because love is hard, sex is, hard, and her hard eyes see past him, sees me, ringfingered, holding his life preserver.

The question she keeps asking is when not if. She still sees herself bridalveil and ring-and whiteness everywhere. Though she longs to stand beside him in clouds of light, each time

she reaches out, she pushes him away. And the currants, since she's so light she no longer eats, are strewn behind her.

If sparrows peck them up, they'll be more nourishing, at least than bread crumbs.

Her father, traitor to her mother, to her, hidden behind a curtain while she struggles again to avoid being the dead girl.

But her would-be groom wants her to be his wild river, so she can flow or open, eddy, and bend. Don't drown, she warns herself, afraid the baby's breath in her hair will unweave when she tries to remember the moves for her lean body and how to take it feet first into rapids then over the falls.

To preserve what we are-he and I- I'm almost willing to let her die.

Or perhaps, without him, she'll eat more than currants, drink more than water. If not, I'll feed her pomegranate seeds, lead her down to the margin of the dark river.

As she rehearses aquatic solos, I will

show her lover a high path, beneath question-mark clouds yet above the treacherous racing water. 